Psychology. Journal of the Higher School of Economics.

2019. Vol. 16. N 1. P. 85-107. DOI: 10.17323/1813-8918-2019-1-85-107

\title{
ENVIRONMENTAL IDENTITY IN RUSSIA: VALIDATION AND RELATIONSHIP TO THE CONCERN FOR PEOPLE AND PLANTS
}

\author{
S. CLAYTON ${ }^{a}$, B.D. IRKHIN ${ }^{b}$, S.K. NARTOVA-BOCHAVER
}

${ }^{a}$ The College of Wooster, 930 College Mall, Wooster, Ohio 44691 USA

${ }^{b}$ National Research University Higher School of Economics, 20 Myasnitskaya Str., Moscow, 101000, Russian Federation

\begin{abstract}
Environmental identity is a self-concept that incorporates and is defined by a relationship with nature. In the current paper the concept is investigated in three empirical studies using the Environmental Identity (EID) scale. Study $1(\mathrm{n}=222)$ was devoted to validating the Russian version of the EID scale. Along with the EID scale, we measured environmental attitudes with the New Environmental Paradigm and Global Awareness of Consequences scales. In line with the original version, the Russian version has a one-factor structure and a good internal consistency $(\alpha=.88)$, and is positively connected with environmental concern, global awareness of consequences, egoistic, altruistic and biospheric values. Study $2(n=94)$ investigated the connection between EID and attitudes toward the plant world using the People and Plants questionnaire. EID predicted all variables describing people's attitudes towards plants: Joy, Aesthetics, Experience of Interaction with Plants, Closeness to Nature, and Ecology. Finally, Study $3(\mathrm{n}=200)$ examined the connection between EID and empathy with nature and people. The Dispositional Empathy with Nature and Interpersonal Reactivity Index scales were used. It was revealed that EID was positively connected and contributed to both types of empathy, more strongly impacting empathy with nature. It is concluded that the Russian version of the EID scale is a valid and reliable instrument, and the EID concept seems to relate to a more general ability to connect with things external to oneself. Hence, it has the potential to be helpful in forming psychotherapeutic programs and in designing restorative environments.
\end{abstract}

Keywords: environmental identity, empathy, nature, plants.

\section{Introduction}

An individual's relationship with nature, and sense of personal connection to nature, is important to study, because it may both underlie concern about environmental issues and relate to a more general moral expansiveness. The present paper has two main goals: to validate the idea of environmental identity in a new cultural context, namely Russia; and to explore the relationship between environmental

This research was supported by the RFBR (Project 19-013-00216 19). 
identity and attitudes toward other people as well as to plants. Previous studies have shown a high predictive role of environmental identity in relation to environmental attitudes and people's positive functioning (Capaldi et al., 2017; Clayton, 2003; Freed, 2015; Kahn \& Peter, 2003). This shows that environmental identity has value in understanding people's response to both environmental protection and personal adaptation. However, another question concerns the relationship between environmental identity and attitude toward the natural and social world (other people). In other words, does a sense of belonging to the natural world necessarily mean recognition and respect for the rest of the world - e.g., plants and other people?

According to the theory of moral expansiveness (Crimston, Bain, Hornsey, \& Bastian, 2016), the extent to which people respect others and care for them depends in part on the distinctions individuals make between entities deemed worthy or unworthy of moral consideration, or people's moral boundaries. Thus, they can include or exclude other living beings from their moral responsibility, leading either to empathy with these entities or to neglecting them. Environmental identity, however, does not necessarily imply closeness to other living organisms or people. It may well happen that people with a high environmental identity, recognizing the importance of their own natural rootedness, nevertheless do not sympathize with other people or living beings at the same time. Thus, after having substantiated and validated the concept of environmental identity in Russian culture, we put forward the following research question: how is environmental identity related to the connection with people and other natural objects (in our study - plants)?

\section{What is Environmental Identity?}

In prehistoric times, people were completely immersed in nature; interaction with nature was crucial for basic survival. As our species evolved, and the societies we built became increasingly complex and diversified, social interactions became more important and sophisticated than human-nature relations. It became easy to draw a line between Humanity and Nature. However, natural roots remain the foundation of modern humans. E. O. Wilson (1984), among others, has argued in his biophilia hypothesis that the predisposition to form an emotional connection to the natural environment is inherited, because such a connection would have been adaptive in the context within which humans were evolving their defining characteristics.

A stable perception of connection to the natural environment is the basis of an environmental identity. Environmental identity reflects an understanding of "identity" as a relatively stable way of thinking about the self, grounded in personal experiences and mediated by socially-constructed interpretations of those experiences. The construct of environmental identity, in particular, was developed to describe a self-concept that incorporates and is defined by a relationship with nature (Clayton, 2003). People with a high in environmental identity think of themselves as connected to, and interdependent with, the natural world. This feeling of kinship seems at least in some cases to motivate environmental protection and prompt environmental activism (Matsuba et al., 2012). 
People have multiple identities - that is, multiple ways of defining themselves, whose importance varies from person to person and whose salience varies according to the social context. Everyone has the potential for an environmental identity, just as everyone has the potential for a gender or racial identity, but the strength of that identity will depend on one's history of meaningful experiences associated with it. Early experiences with nature, particularly in the company of significant others, seem to be important in the development of a natural identity (Matsuba \& Pratt, 2013; Chawla, 1999, 2007; Prévot, Clayton, \& Mathevet, 2018). Matsuba et al. (2012) also argue that an environmental identity is at least somewhat dependent on one's developmental stage, as a certain level of maturity and generativity may be required to commit to an identity and be concerned about one's impact on the world. Although their analysis found no age effects on environmentalism, they did find that generativity and identity maturity were both correlated with environmental identity as well as with environmentalism. Green, Kalvaitis, and Worster (2016) have described a developmental model of environmental identity development that incorporates the interaction between developmental stage and experiences with nature.

The natural environment has the potential to form an important part of identity for three reasons. First, it is a source of emotionally resonant and meaningful experiences for many people. This may be attributed in part to the multisensory nature of environmental experiences, which makes them memorable. Second, it is a context that appears to foster self-reflection. Indeed, many people describe a natural environment as a place where they would want to go to think about their important goals and values (Korpela, Hartig, Kaiser, \& Fuhrer, 2001). Finally, it has the potential to satisfy some basic human needs. According to Self-Determination Theory (Ryan \& Deci, 2003), identities are adopted in the service of needs such as autonomy, esteem, and belonging. Environmental identities may help to satisfy each of these needs (Clayton, 2003), but perhaps particularly the need for connection and belonging. Many people describe their nature experiences as making them feel "connected to everything else" and "a part of the whole interdependent system".

The possibility of an environmental identity is important to examine because identities affect people's responses to events and issues. Topics that are self-relevant attract more attention and elicit a stronger emotional response. People are also motivated to validate and defend their identities, so that - all things being equal - they will be more likely to behave in a way that demonstrates their connection to the environment and that allows them to feel positive about the environment. Thus, a strong environmental identity should encourage a more pro-environmental behavior.

\section{Measurement of Environmental Identity}

Clayton (2003) developed the Environmental Identity (EID) scale, a 24-item questionnaire, which was later modified into a shorter, 11-item version (Clayton, 2012). This scale has strong internal reliability and test-retest reliability. The principal components analysis has typically found only a single dominant factor, 
though occasionally a more complex structure emerges; for example, Fritsche and Häfner (2012) found two factors among German students, one interpreted as reflecting contact with nature and one as reflecting self-definition; Olivos and Aragonés (2011) identified four factors, including self-definition, environmental enjoyment, environmental appreciation, and environmentalism. In known-groups comparisons, Clayton (2003) found significant differences between environmental studies students and a comparison group of students in the U.S.; Matsuba et al. (2012) found that environmentalists scored significantly higher on EID than did a comparison group in Canada; while Scopelliti et al. (2018), in a cross-national study, found that European leaders who were distinguished by their actions for biodiversity scored higher on environmental identity than did similarly-situated individuals who were not known for such actions.

As expected, EID scores are strongly correlated with environmental concern, values, behavior, and behavioral intention (Clayton, 2003; Matsuba et al., 2012; Olivos \& Aragonés, 2011; Scopelliti et al., 2018; Tam, 2013b; Watson, Hegtvedt, Johnson, Parris, \& Subramanyam, 2017). Of particular note for the present paper, Kiesling and Manning (2010) found that EID was positively correlated with several scales related to gardening, including pro-environmental gardening behavior, engagement with natural processes, and an overall sense of gardening identity. Fritsche and Häfner (2012), testing the hypothesis that mortality salience would reduce environmental concern, found that this effect only held true for participants low in EID. Mortality salience that refers to the extent to which people are thinking about the possibility of their own death, increases the need for self-affirmation as a symbolic defense and can reduce concern for things that are not self-relevant. Fritsche and $\mathrm{H} д$ fner argued that people high in EID are able to achieve self-affirmation through expression of environmental concern.

Several other measures designed to assess a person's relationship to nature have been developed in the past few decades (e.g., Nature Relatedness, Connectedness to Nature, Inclusion of Nature in the Self). These all tend to have positive intercorrelations, though some studies show that the reliability of EID is slightly higher than some of the other scales (Brügger, Kaiser, \& Roczen, 2011; Olivos \& Aragonés, 2011; Tam, 2013).

\section{Cultural Differences}

The meaning and strength of an environmental identity may vary across cultures. It is difficult to interpret the difference between scores from different countries unless studies have been specifically set up to compare those countries, due (if for no other reason) to demographic differences among samples. The EID scale has been successfully used in (at least) Canada, China, France, Germany, Hungary, Spain, Switzerland, and Turkey, with good internal reliabilities and meaningful predictive validity. Nevertheless, the cultural context is likely to vary in the way it provides a foundation for environmental identity. For example, Turkey has a national culture that seems to stress care for the natural environment, and a sense of national identity was found to correlate with environmental identity among Turkish respondents (Clayton \& Kilınç, 2013). 
Capaldi et al. (2017) suggest that the Russian context for a relationship with nature is characterized by two themes: one, a dominionistic view that natural resources should be exploited for human wellbeing; and the other, a more relational view of the earth as our universal mother. However, they found relatively similar relationships between a sense of connection with nature (measured with the Connectedness with Nature Scale), on the one hand, and wellbeing, on the other, in Russia as compared to Canada and Japan. There was no evidence that the levels of connection to nature, or the role of connection to nature in predicting wellbeing, were significantly different across the three countries.

\section{Relation to Other Constructs}

A sense of environmental identity is fundamentally a recognition of one's own interdependence with a larger collective. It is a personal identity that also has implications for social connections; it should thus be related to other, perhaps nonenvironmental, perspectives and attitudes that emphasize connections and the larger group. Consistent with this, Clayton found that it was positively associated with a collectivist worldview (2003), and negatively associated with social dominance orientation, which is a perspective that the world is hierarchically organized (2008). A global identity - that is, a tendency to identify with, and feel connected to, people around the globe - is also negatively associated with social dominance orientation, and positively associated with pro-environmental behavior (Reese, 2016). It may be that the ability to transcend one's personal limits and perceive one's status as part of a system is the important aspect of EID. (It is noteworthy, though, that the Global Identity measure includes things that seem to tap into environmental identity, such as "I feel connected with the whole earth.")

Brügger et al. (2011) also relate EID to a measure they call "Disposition to Connect with Nature”, which includes items assessing the attention paid to plants and other elements of the natural world. Despite the fact that the EID scale contains no such items, the underlying trait that it measures is likely to promote attention to nature. Other research has found Connectedness to Nature - a measure that is similar to the EID measure - to be strongly correlated with the Engagement with Natural Beauty scale that measures the degree to which people perceive beauty in nature and respond emotionally (Zhang, Howell, \& Iyer, 2014).

In sum, environmental identity is an important concept, because it relates to environmentally sustainable behavior, affects our well-being, and influences decision-making. It is also important to examine the cultural differences in environmental identity that could help to illuminate the way in which culture affects and constructs the individual relationship with nature. The present research aimed to investigate the construct of environmental identity in Russia and particularly how it relates to a more expansive sphere of moral concern. We conducted a series of empirical studies: the first was primarily intended to validate the EID scale in Russia; the second explored its relationship to a People and Plants scale; and the third examined its relationship with interpersonal empathy. 


\section{Study 1}

In order to assess environmental identity in Russian culture, Clayton's (2003) EID scale was chosen for preliminary adaptation to the Russian context (see Appendix A). EID is a well-known scale that showed high levels of reliability in previous research. Due to Clayton's (2003) arguments on the factor structure of the scale it was hypothesized 1) that the Russian version of the EID scale will retain the same one-factor structure as the initial one. The original, longer version of the scale was used to enable comparison to the earlier factor analysis.

In order to check the convergent validity of the translated scale, Dunlap's New Environmental Paradigm (Dunlap \& Van Liere, 1978; Dunlap et al., 2000) and the Global Awareness of Consequences (Stern \& Dietz, 1994) scale were chosen for comparison. While original validation procedure contained different methods, in previous studies (Matsuba et al., 2012), NEP and GAC scales reported correlations with the EID scale in English speaking countries, so it was hypothesized 2) that the Russian version of the EID scale would correlate with the listed scales in the current study. The translated scale also was tested for internal consistency, so it was hypothesized 3) that the alpha-score would be close to Clayton's result $(\alpha=.90)$.

Procedure. 222 respondents participated (180 female, $\mathrm{M}_{\text {age }}=23.6, \mathrm{SD}_{\text {age }}=6.7$ ). Most individuals were undergraduate students from Russian universities (58.7\%), 55 graduated from university $(24.7 \%)$, and 37 completed high schools $(16.6 \%)$. The socio-demographic quality of the sample was expected, because the questionnaire link was advertised via social media and placed in some universities' social media. Data was gathered via online questionnaire platform and did not require participants to be present. Participation in the study was completely voluntary.

The questionnaire was distributed and filled in via Internet; the data was then downloaded and processed in IBM SPSS software.

The 24-item Environmental Identity scale was translated by multiple professional English-speaking psychologists; several prototypes of the scale were developed before reaching the actual version used in the current study, each iteration included a back-translation via several online translation programs (Google Translate, DeepL Translator, etc.), a feedback collection and a discussion (see Appendix 2).

The New Environmental Paradigm scale, developed by Dunlap (Dunlap \& Van Liere, 1978) to measure environmental concern, includes fifteen items: eight statements that align the respondent as a supporter of a new environmental paradigm ("The balance of nature is very delicate and easily upset", "Plants and animals have as much right as humans to exist"), which stands for a new, more environmentaloriented world view; and seven that are associated with the dominant social paradigm (DSP) reflecting an anthropocentric position and orientation to nature in an instrumental way ("The balance of nature is strong enough to cope with the impacts of modern industrial nations", "Humans were meant to rule over the rest of nature").

The Global Awareness of Consequences (GAC) scale is based on the tripartite model of environmental concern introduced by Stern and Dietz (1994). It is used 
for measuring general level of environmental concern or for distinguishing the values underlying the environmental awareness of the subject. The GAC scale consists of nine items placed on a 5-point Likert scale, and has three subscales: egoistic, altruistic and biospheric values.

Results. Descriptive statistics and reliabilities of the methods are presented in Table 1. Overall, reliability tests showed good internal reliabilities, including translated methods.

Factor analyses indicated three distinct factors explaining 31\%, 9\% and 5\% of the variance respectively. The principal components analysis was used because the primary purpose was to identify and compute composite scores for the factors underlying the translated version of the EID scale. The scree plot indicates significant reduction of eigenvalues after the first factor. Solutions for three, four, five and six factors were each examined using varimax and oblimin rotations of the factor loading matrix. The one-factor solution, which explained $31 \%$ of the variance, was preferred because of the insufficient number of primary loadings on the second factor and subsequent factors and the drop of the eigenvalues after the first factor.

Furthermore, it was also found that the EID scale displays significant correlations with environmental concern and all of the GAC scales (see Table 2). These connections give a good evidence for convergent validity of the Russian version of EID scale.

Table 1

Descriptive Statistics of the Scales

\begin{tabular}{|l|c|c|c|c|c|c|c|}
\hline \multicolumn{1}{|c|}{ Scale } & M & Mdn & Mode & Min & Max & SD & Cronbach's $\boldsymbol{\alpha}$ \\
\hline EID & 2.58 & 2.54 & 2.71 & 1.00 & 5.00 & .49 & .88 \\
\hline NEP & 3.60 & 3.60 & 3.40 & 1.00 & 5.00 & .41 & .75 \\
\hline GAC (the main score) & 4.05 & 4.11 & 4.44 & 1.00 & 5.00 & .45 & .74 \\
\hline Egoistic value & 4.34 & 4.33 & 4.00 & 1.00 & 5.00 & .57 & .71 \\
\hline Altruistic value & 4.16 & 4.33 & 4.67 & 1.00 & 5.00 & .56 & .74 \\
\hline Biospheric value & 3.67 & 3.66 & 3.67 & 1.00 & 5.00 & .57 & .77 \\
\hline
\end{tabular}

Table 2

Connections between Environmental Identity and Investigated Variables

\begin{tabular}{|l|c|c|c|c|c|c|}
\hline \multicolumn{1}{|c|}{ Variables } & $\mathbf{1}$ & $\mathbf{2}$ & $\mathbf{3}$ & $\mathbf{4}$ & $\mathbf{5}$ & $\mathbf{6}$ \\
\hline 1. Environmental identity & - & & & & & \\
\hline 2. Environmental concern (NEP) & $.39^{* *}$ & - & & & & \\
\hline 3. Global awareness of consequences & $.27^{* *}$ & $.46^{* *}$ & - & & & \\
\hline 3. GAC Egoistic values & $.32^{* *}$ & $.31^{* *}$ & $.77^{* *}$ & - & & \\
\hline 4. GAC Altruistic values & $.18^{* *}$ & $.31^{* *}$ & $.85^{* *}$ & $.52^{* *}$ & - & \\
\hline 5. GAC Biospheric values & $.14^{*}$ & $.43^{* *}$ & $.76^{* *}$ & $.30^{* *}$ & $.47^{* *}$ & - \\
\hline
\end{tabular}

Note. ${ }^{*} p<.05,{ }^{* *} p<.01$. 
Discussion. In general, Russian respondents scored lower than has been found for U.S. and Canada subjects in other studies $(\mathrm{M}=55.78$ according to the original scoring system vs. Canada $\mathrm{M}=60.75$ vs. US $\mathrm{M}=72.64$ ) (Matsuba et al., 2012) on the EID scale. As expected, the EID scale translation returned a high reliability, $\alpha=.88$, which is close to the original result. Factor analyses indicated one dominant factor accounting for $31 \%$ of variance, and two minor ones: environmentalism $(9 \%)$ and environmental appreciation (5\%). Hence, the original factor structure was retained as it was described by Clayton (2003). Additional factors could emerge when the method is administered in a more diverse sample. The found factors coincide with Olivos and Aragonés' (2011) findings, as environmentalism and environmental appreciation were distinct factors in their research with the EID scale.

Results also showed significant connections with constructs familiar to environmental identity - environmental concern and awareness of consequences demonstrating good convergent validity of the adapted instrument and making it a fair method for further endorsement by the Russian research community.

Clayton (2003) describes environmental perspective as more compatible with collectivism than with individualism, since it highlights the importance of interdependence with ecosystem and refers to duties and obligations for the sake of a better world. Russian culture has lived through periods of both dominating collectivism and individualism, and the latter appears to be confronting a collectivist past in modern days (Mamontov, Kozhevnikova, \& Radyukova, 2014). While collectivist cultures display willingness to sacrifice their own resources in order to support the group at large, individualistic subjects tend to prioritize their own needs before the needs of the group - however, the cultural difference perceived in environmental identity scores here requires additional investigation.

The theory of moral expansiveness (Crimston et al., 2016) provides another perspective for the interpretation of the obtained data. The fact that environmental identity is more strongly connected with egoistic values, more weakly with altruistic ones and even more weakly with biospheric values, makes it useful to further investigate its relations with other attitudes toward people and natural entities, in order to see if an environmental identity is generally related to a larger scope of concern. This is the project of the next studies.

To sum up, we can conclude that all of the Hypotheses were fully confirmed, and the EID scale is a useful method for measuring environmental identity in Russian.

Studies 2 and 3 investigated the relationship between EID and other variables. Study 2 looked at the connections between EID and attitudes toward plants. In Study 3 , the EID scale was used in order to find and test relations of environmental identity to environmental concern and empathy.

\section{Study 2}

This study was aimed at investigating the connections between environmental identity and awareness of the importance of plants as part of the natural world. The importance of a connection with nature, and particularly with flora, and especially for urban residents, cannot be overestimated: nature plays a restorative function, 
delivers aesthetic pleasure, supports mental health, and helps people to discover their own individualities (Bringslimark, Hartig, \& Patil, 2009; Elings, 2006; Martens, Gutscher, \& Bauer, 2011; Raanaas, Evensen, Rich, Sjıstrım, \& Patil, 2011). Both active and passive interactions with the plant world, including walking, planting, or the observation of indoor plants, increase positive functioning in individuals. To sum up, interactions with plants can be a very important psychological resource. Therefore, research on all angles of interaction between people and nature is promising. The attitude to the plant world as a topic increasingly attracts the attention of researchers in different fields of knowledge; even such an area as floropoetics that examines the image of plants in literature, is justified (Sharafadina, 2011).

At the same time, in Russia, the attitude to plants as a part of environmental psychology is still in its infancy (Chistopol'skaya, Enikolopov, Nikolaev, \& Semikin, 2017). This is surprising if we take into account that Russia was an agricultural country for many centuries, and in fact every Russian has among their ancestors villagers or farmers. The limited previous research shows, however, that positive relations with plants and flowers in Russians predict not only peoples' subjective well-being but their moral world view and pro-social attitudes as well (Muhortova \& Nartova-Bochaver, 2015). This makes the study of relations to the plant world very topical.

At the same time, environmental identity and attitudes to plants are not synonyms. It is possible that people with a strong environmental identity prefer interaction with animals or inanimate nature (for example, different types of tourism). That is why it is important to study whether an environmental identity is a source of generating the relationship to nature in its different forms.

The current study partially fills this gap. As environmental identity is a source of the broad spectrum of environmental attitudes (Clayton, 2012) we have put forward the following Hypothesis: environmental identity is positively connected with awareness of the plant world.

Procedure. In this study, 94 students from Moscow universities participated (78 female, $\mathrm{M}_{\text {age }}=18.6, \mathrm{SD}_{\text {age }}=1.2$ ). Data was collected from students in class as a part of their individual home work in a course on "Psychology of Individual Differences" during 2016-2017. Participation was anonymous and voluntary; participants were granted extra credits. To get information concerning environmental identity, the Russian version of EID was used (Clayton, 2012; see also Study 1). To assess attitudes towards the plant world, the People and Plants questionnaire (PaP) was used (Muhortova \& Nartova-Bochaver, 2015). PaP consists of five scales and includes 32 items. The Joy scale (11 items) assesses positive emotions that appear when people observe plants and flowers or interact with them. An example of the item: "When my plants die, I always get upset". The Esthetics scale (8 items) emphasizes beauty of plants. An example of the item: "I like to photograph plants and flowers". The Experience of Interaction scale (4 items) shows how experienced in caring on plants individual is. An example of the item: "I come back with any plant (seeds, seedlings, cuttings) from every trip". The Closeness to nature scale (6 items) measures general positive attitudes to the plant world. An example of the 
item: "I feel a surge of positive warm feelings while in the woods". Finally, the Ecology scale (3 items) describes the value of plants in the context of ecological situation. An example of the item: "A person should take care of plants, because life on Earth is impossible without them".

Results. As our sample was not balanced by gender, we calculated all our results on the total sample. First of all, score means, reliabilities, and correlations between EID and PaP scores were calculated (see Tables 3 and 4).

As expected, all of PaP scores were positively connected with environmental identity which means that people who have general positive emotional connections with nature tend to treat plants and flowers well. More specifically, they experience the joy of looking at plants and flowers, appreciate the beauty of living plants as well as images of them, they love and know how to care for plants. Moreover, they feel their closeness to nature in general and understand the role of plants in preserving the eco system.

Results are very homogeneous and easily interpreted: in accordance with our expectations, environmental identity can be related to a broad spectrum of connections with plants.

Discussion. Despite the apparent simplicity, these results are expressive and seem to be promising for further research and psychological counseling. Firstly, they once more confirm the content validity of the Russian version of the EID scale by Clayton (2012). Further, although the plant world is not the whole of nature (that also includes the world of animals and inanimate phenomena), the revealed connections show that the construct of environmental identity is quite universal. Thirdly, our research was explorative, and in fact we haven't any sound theory regarding attitudes to plants in Russian citizens. Thus, we could expect that young

Table 3

Descriptive Statistics of the Scales

\begin{tabular}{|l|c|c|c|}
\hline \multicolumn{1}{|c|}{ Measure } & M & SD & Cronbach's $\boldsymbol{\alpha}$ \\
\hline Joy & 2.47 & 1.06 & .94 \\
\hline Esthetics & 2.78 & .98 & .88 \\
\hline Experience & 1.86 & 1.01 & .82 \\
\hline Closeness to Nature & 3.01 & 1.01 & .87 \\
\hline Ecology & 3.22 & 1.01 & .81 \\
\hline Environmental Identity & 80.13 & 22.56 & .78 \\
\hline
\end{tabular}

Table 4

Connection ( $r s$ ) between Environmental Identity and PaP Scores

\begin{tabular}{|c|c|c|c|c|}
\hline Joy & Esthetics & Experience & Closeness to Nature & Ecology \\
\hline .68 & .60 & .58 & .63 & .46 \\
\hline
\end{tabular}

Note. All connections are significant at $p<.000$. 
citizens, on the contrary, do not identify themselves with nature and do not show interest in plants at all. In this case, it would be relevant to search for other sources of natural psychotherapy and self-support for this population. As these results show, experiences of plants were fairly low in this sample, but feelings of closeness to nature and to natural ecology were fairly strong.

\section{Study 3}

Environmental identity resembles an archetypical or even a Darwinist approach to human-nature relations explicitly showing that mankind may have left the cradle of wilderness but remains internally its child. While social identities are based on social experiences, environmental identities are formed by experiences with the natural environment. An identity approach considers environmental concern as a significant part of one's self - a product of phenomenal nature. Clayton (2003) defines environmental identity as an assortment of beliefs about the self and a motivator of particular ways of interacting with the world meaning that identity can be a product and a force.

However, environmental identity endorses the idea of interdependence between various parts of nature, considering mankind as a small part of an enormous system. The ability to feel unified with a much larger natural force and experience interconnection with the world resembles the transcendental self-concept. It follows that environmental concern in this case can be perceived as a concern for one's transcendental self: if the whole system is endangered, then the small parts of it also experience threat.

Exploring the idea of transcendence of human consciousness and its interdependence with nature, Schultz (2000) experimented with the concept of empathy with nature. In his study, natural environment and self are linked via the process of internalization of the observable or imaginary nature which serves as a mediator in human-nature relations. While empathy is mostly studied as a social phenomenon (e.g. Davis, 1983; Rothschild, 2006), the effects of dispositional empathy with nature were salient in Schultz's studies. Empathy with nature appears as a young and yet not completely developed construct, despite its promising theoretical potential, and needs exploration, which is one of the goals of the current study. Based on the described transcendence of empathy, we assumed that people with higher environmental identity would empathize more with other life forms, and formed a Hypothesis 1: Environmental identity is positively connected with environmental empathy.

While the current study explores the connection between empathy end environmental identity, it is important to check the connection between environmental identity and social empathy as well. It is logical, to assume that being included in the universal ecosystem, humans would display care not only about the whole system as in Schultz's studies on environmental concern (2000), but also tend to treat sole humans as a part of this system leading to increased sensitivity to others. Hence, we propose a Hypothesis 2: Environmental identity is positively connected to social empathy. 
Procedure. A total of 200 respondents participated in the study (168 female, $\mathrm{M}_{\text {age }}=22.5, \mathrm{SD}_{\text {age }}=6.2$ ); the majority of the respondents were women (84\%). Most of the individuals were undergraduate students from Russian universities (54\%), 55 graduated from university $(27.5 \%)$, and 37 completed high school (18.5\%). Data was gathered via online questionnaire platform; participation in the study was completely voluntary.

Three methods formed the base of the questionnaire, apart from a social-demographic block constructed of age, sex, and education information.

Clayton's EID scale was used to measure the environmental identity of the respondents.

In order to measure environmental empathy, Dispositional Empathy with Nature scale was used (DENS) (Stern et al. 1995). This is based on Davis's IRI scale and collects data using two subscales: Perspective-Taking (e.g. "I imagine how I would feel if I were the suffering animals and plants", "I can very easily put myself in the place of the suffering animals and plants") and Empathetic Concern (e.g. "I feel as though I were one of the suffering animals and plants", "I have tender, concerned feelings for the suffering animals and plants").

Davis's Interpersonal Reactivity Index (IRI) was used to measure social empathy. In order to shorten the questionnaire, only two of the four subscales were used: Perspective-Taking (e.g. "I try to look at everybody's side of a disagreement before I make a decision", "When I'm upset at someone, I usually try to "put myself in his shoes" for a while") and Empathetic Concern (e.g. "I am often quite touched by things that I see happen", "Other people's misfortunes do not usually disturb me a great deal" - a reverse item). Apart from shortening the measure, no additional changes were made.

Results. Descriptive statistics and reliabilities of the scales are presented in the Table 5.

Reliabilities tests showed good internal consistency in our study. After checking internal consistency, data was grouped and passed through a series of non-parametric tests (Table 6).

A linear regression analysis was used to investigate whether the identity predicts environmental empathy and social empathy or not (see Table 7). As revealed outcomes show, both empathy types were significantly predicted by EID; environmental empathy was predicted more strongly $\left(R^{2}=.33\right.$ compared to $\left.R^{2}=.09\right)$.

Discussion. All instruments used in this study displayed good internal consistency. In particular, the EID scale returned $\alpha=.88$, which is close to Clayton's results (2003), and provides support for the translated scale (see Study 1).

As expected, a significant correlation was found between the EID and DENS scales; both subscales correlated with EID at a strongly significant level $(p<.01)$. It means that environmental identity is connected with environmental empathy confirming our Hypothesis 1.

A significant correlation between the EID and IRI scales was also found at a strongly significant level $(p<.01)$ which means that people' environmental identity is connected with social empathy, in accordance with Hypothesis 2. While two 
Descriptive Statistics and Reliabilities of the Scales

\begin{tabular}{|l|c|c|c|c|c|c|c|}
\hline \multicolumn{1}{|c|}{ Measure } & M & Mdn & Mode & Min & Max & SD & Cronbach's $\boldsymbol{\alpha}$ \\
\hline $\begin{array}{l}\text { Environmental Identity } \\
\text { scale }\end{array}$ & 2.57 & 2.54 & 2.38 & 1.00 & 5.00 & .50 & .88 \\
\hline $\begin{array}{l}\text { Dispositional Empathy } \\
\text { to Nature }\end{array}$ & 2.49 & 2.42 & 2.25 & 1.00 & 5.00 & .61 & .92 \\
\hline DENS Perspective-Taking & 2.46 & 2.25 & 2.00 & 1.00 & 5.00 & .70 & .86 \\
\hline DENS Empathetic Concern & 2.58 & 2.50 & 2.50 & 1.00 & 5.00 & .60 & .86 \\
\hline $\begin{array}{l}\text { Interpersonal Reactivity } \\
\text { Index }\end{array}$ & 2.73 & 2.79 & 2.79 & 1.00 & 5.00 & .33 & .73 \\
\hline IRI Perspective-Taking & 2.79 & 2.86 & 2.86 & 1.00 & 5.00 & .37 & .71 \\
\hline IRI Empathetic Concern & 2.70 & 2.71 & 2.57 & 1.00 & 5.00 & .38 & .72 \\
\hline
\end{tabular}

Table 6

Connection ( $r s$ ) between Environmental Identity, Environmental Empathy and Social Empathy Subscales

\begin{tabular}{|c|c|c|c|}
\hline $\begin{array}{c}\text { DENS } \\
\text { Perspective-Taking }\end{array}$ & $\begin{array}{c}\text { DENS } \\
\text { Empathetic Concern }\end{array}$ & $\begin{array}{c}\text { IRI } \\
\text { Perspective-Taking }\end{array}$ & $\begin{array}{c}\text { IRI } \\
\text { Empathetic Concern }\end{array}$ \\
\hline .47 & .51 & .26 & .29 \\
\hline
\end{tabular}

Note. All connections are significant at $p<.01$.

Table 7

Predictive Role of Environmental Identity for Environmental and Social Empathy Scores

\begin{tabular}{|l|c|c|c|c|}
\hline \multicolumn{1}{|c|}{ Measure } & $\boldsymbol{\alpha}$ & $\boldsymbol{R}^{\mathbf{2}}$ & $\boldsymbol{F ( 1 , 1 9 8 )}$ & $\boldsymbol{p}$ \\
\hline Environmental empathy (DENS) & .77 & .33 & 96.41 & .000 \\
\hline Social empathy (IRI) & .19 & .09 & 19.67 & .000 \\
\hline
\end{tabular}

aspects of empathy were both significantly connected to EID, environmental empathy subscales display stronger correlation than social empathy.

Moreover, EID also appeared as a significant predictor in both environmental and social empathy, regarding linear regression results. It means that the way we perceive ourselves as parts of nature significantly influences our relations with nature and other people in a positive way. This finding, along with support to existing studies of Schultz $(2000,2001)$, opens a promising field for future research on 
environmental identity and its positive effect on mental health and well-being. At the same time, it is somewhat different from the Schultz (2001) data, which established a negative association between the connection with nature and egoistic values. This difference may be due to the cultural or age characteristics of the sample. On the other hand, it is possible that the investigated connections are nonlinear, and in this case, the mediating variables need to be added.

\section{General Discussion}

Together, the present studies serve several purposes. First, they confirm that environmental identity is a valid construct, and the EID scale a reliable measure in Russian culture of that construct. Although not unexpected based on previous research with the EID scale in other countries, this finding is important in paving the way for further research, including cross-cultural studies. Russia presents a context for human-nature relations that is distinct from those in Western nations in the way it contains both individualistic and collectivist themes.

At the same time, the connections of environmental identity with other constructs of similar content generally correspond to those obtained in other countries (Capaldi et al., 2017; Schultz et al., 2001). The main difference from Schultz et al. (2001)'s data was that in Russia the connection of environmental identity with egoistic values was positive. This interesting fact may suggest that in Russia people are in a synergistic rather than complementary relationship with nature, in the sense that their personal interests do not contradict the interests of the natural world as a whole. However, this interpretation needs further research. Future qualitative research could add to our understanding of the way in which nature is conceptualized in Russia.

Second, these results show a connection between environmental identity and the attitude toward plants, that provides additional evidence for the validity of the EID scale. Finally, the results of Study 3 uncover a significant correlation between EID and empathy, not only toward plants and nature but towards other people. This suggests that the EID is related to a broader tendency to be aware of connections to others, including both human and nonhuman entities in our scope of concern. Because environmental identity is associated with early experiences with nature, it may be that early experiences with nature - perhaps even experiences with nature as an adult - can promote concern for other people and ability to take alternative perspectives.

However, the outcomes obtained require further study of how people with high environmental identity rank the value of other natural objects and forms of life. It may happen that the preference for nature to society can also lead to negative consequences in the field of pro-social attitudes. To investigate this question, information is needed about the emotional connectedness with nature and people, the history of human relations with nature, as well as the relationship of environmental identity with other identities, including cultural, religious, and social ones. We can assume that, depending on the degree of the schism between these identities, different types of personality will result, for example, relatively Natural, Social, 
Universal, and Marginal (between culture and nature) types. In the authors' opinion, this finding goes beyond the specific phenomena for Russia and can be studied in a wide cultural space.

Although somewhat preliminary, the results of the current study suggest that many Russians do feel some level of environmental identity. Moreover, this is a working construct as it forms a system of dense connections with other constructs.

The field of environmental psychology is growing in Russia and worldwide as people become more aware of the interdependence between human and environmental wellbeing. The study of individual relationships with the natural environment is an important theme in this field.

\section{Conclusion}

These results could be relevant to the field of psychological counseling, especially with younger students, suggesting that opportunities for interaction with natural environments could have a positive effect on wellbeing. As the first year of adaptation to the university is stressful, it is necessary to attract all possible resources in order to overcome this. The results obtained here could be valuable for designers and for the organization of guided and un-guided self-help techniques (Nartova-Bochaver, 2009).

Along these lines, the opportunity to contact with nature in the form of its observation, care for plants and pets, or just walking in the park should be promoted. Moreover, such events should be organized by the psychological services of universities, especially those located in large cities. Another point of practical application of the results is the developing design of restorative facilities using images of the natural world or its living representatives.

At the same time, the study has a few limitations that are expected to be overcome in future research. First of all, the limitations of the current study are shaped by the sample characteristics: there were significantly more female respondents (84\%), and most of the participants were younger students from various Russian universities (54\%). A more diversified sample is advised for future research in order to substantiate our findings. Furthermore, it is possible that, in the absence of control over social desirability, our respondents perceived certain responses as socially desirable, and the level of environmental concern as well as environmental identity could be lower in the general population. More research is needed to replicate and extend these results. Further, the sample was not randomized by gender, or by objective data on the respondents' competence and experience in dealing with nature, and was not free from self-selection bias. In future research, the procedure of data collection should be changed in the direction of greater representativeness.

Finally, we may assume that the majority of the received connections might have a nonlinear character. To get more nuanced results, it is necessary to conduct a study adding mediating and moderating variables. 


\section{References}

Bringslimark, T., Hartig, T., \& Patil, G. G. (2009). The psychological benefits of indoor plants: A critical review of the experimental literature. Journal of Environmental Psychology, 29(4), 422-433.

Brügger, A., Kaiser, F. G., \& Roczen, N. (2011). One for all? Connectedness with nature, inclusion of nature, environmental identity, and implicit association with nature. European Psychologist, 16, 324-333.

Capaldi, C. A., Passmore, H. A., Ishii, R., Chistopolskaya, K. A., Vowinckel, J., Nikolaev, E. L., \& Semikin, G. I. (2017). Engaging with natural beauty may be related to well-being because it connects people to nature: Evidence from three cultures. Ecopsychology, 9(4), 199-211.

Chawla, L. (1999). Life paths into effective environmental action.Journal of Environmental Education, $31,15-26$.

Chawla, L. (2007). Childhood experiences associated with care for the natural world. Children, Youth and Environments, 17, 144-170.

Chistopol'skaya, K. A., Enikolopov, S. N., Nikolaev, E. L., \& Semikin, G. I. (2017). Svyaz' s prirodoi: vklad v dushevnoe blagopoluchie [Connection with nature: a contribution to mental well-being]. In Perspektivy psihologicheskoj nauki i praktiki [Prospects of psychology as a science and practice] (pp. 764-767). Moscow: State University of Design and Technology. (in Russian)

Clayton, S. (2003). Environmental identity: A conceptual and an operational definition. In S. Clayton \& S. Opotow (Eds.), Identity and the natural environment (pp. 45-65). Cambridge, MA: The MIT Press.

Clayton, S. (2008). Attending to identity: Ideology, group membership, and perceptions of justice. In K. Hegtvedt \& J. Clay-Warner (Eds.), Advances in group processes: Justice (pp. 241-266). Bingley, UK: Emerald.

Clayton, S. (2012). Environment and identity. In S. Clayton (Ed.), Oxford handbook of environmental and conservation psychology (pp. 164-180). New York: Oxford.

Clayton, S., \& Kılınç, A. (2013). Proenvironmental concern and behavior in Turkey: The role of national and environmental identity. PsyEcology, 4, 311-330.

Crimston, D., Bain, P. G., Hornsey, M. J., \& Bastian, B. (2016). Moral expansiveness: Examining variability in the extension of the moral world.Journal of Personality and Social Psychology, 111(4), 636-653.

Davis, M. H. (1983). Measuring individual differences in empathy: Evidence for a multidimensional approach. Journal of Personality and Social Psychology, 44(1), 113-126.

Dunlap, R. E., \& Van Liere, K. D. (1978). The "New environmental paradigm". The Journal of Environmental Education, 9(4), 10-19.

Dunlap, R. E., Van Liere, K. D., Mertig, A. G., \& Jones, R. E. (2000). New trends in measuring environmental attitudes: measuring endorsement of the new ecological paradigm: a revised NEP scale. Journal of Social Issues, 56(3), 425-442.

Elings, M. (2006). People-plant interaction: the physiological, psychological and sociological effects of plants on people. In Farming for health (pp. 43-55). Dordrecht: Springer.

Freed, A. (2015). Exploring the link between environmental identity, behaviors and decision making (Doctoral dissertation, Michigan State University). Retrieved from https://d.lib.msu.edu/etd/3354/datastream/OBJ/download/EXPLORING_THE_LINK_BET WEEN_ENVIRONMENTAL_IDENTITY_BEHAVIORS_AND_DECISION_MAKING.pdf

Fritsche, I., \& Häfner, K. (2012). The malicious effects of existential threat on motivation to protect the natural environment and the role of environmental identity as a moderator. Environment and Behavior, 44(4), 570-590. 
Green, C., Kalvaitis, D., \& Worster, A. (2016). Recontextualizing psychosocial development in young children: a model of environmental identity development. Environmental Education Research, 22(7), 1025-1048.

Kahn, P. H., \& Peter, H. (2003). The development of environmental moral identity. In S. Clayton \& S. Opotow (Eds.), Identity and the natural environment (pp. 113-134). Cambridge, MA: The MIT Press.

Kiesling, F. M., \& Manning, C. M. (2010). How green is your thumb? Environmental gardening identity and ecological gardening practices. Journal of Environmental Psychology, 30(3), 315-327.

Korpela, K. M., Hartig, T., Kaiser, F. G., \& Fuhrer, U. (2001). Restorative experience and self-regulation in favorite places. Environment and Behavior, 33(4), 572-589.

Mamontov, V. D., Kozhevnikova, T. M., \& Radyukova, Y. Y. (2014). Collectivism and individualism in modern Russia. Asian Social Science, 10(23), 199.

Martens, D., Gutscher, H., \& Bauer, N. (2011). Walking in "wild" and "tended" urban forests: The impact on psychological well-being. Journal of Environmental Psychology, 31(1), 36-44.

Matsuba, M. K., \& Pratt, M. W. (2013). The making of an environmental activist: A developmental psychological perspective. In M. K. Matsuba, P. E. King, \& K. C. Bronk (Eds.), Exemplar methods and research: Strategies for investigation. New Directions for Child and Adolescent Development, 142, 59-74.

Matsuba, M. K., Pratt, M. W., Norris, J. E., Mohle, E., Alisat, S., \& McAdams, D. P. (2012). Environmentalism as a context for expressing identity and generativity: Patterns among activists and uninvolved youth and midlife adults. Journal of Personality, 80(4), 1091-1115.

Muhortova, E. A., \& Nartova-Bochaver, S. K. (2015). Rastitel'nyj mir kak predmet ehkologicheskogo soznaniya i resurs stihijnoj terapii sovremennyh rossiyan [Flora as a subject of ecological consciousness and a resource of spontaneous therapy of modern Russians] In Gumanitarnye $i$ estestvenno-nauchnye faktory resheniya ehkologicheskih problem i ustojchivogo razvitiya. Materialy [Humanitarian and natural-scientific factors of solving environmental problems and sustainable development. Materials] (pp. 5-7). Novomoskovsk: URAO. (in Russian)

Nartova-Bochaver, S. K. (2009). Edinstvo sub"ekta i bytiya kak osnova estestvennoj psihoterapii [The unity of the subject and being as the basis of natural psychotherapy]. In Sub"ektnyj podhod v psihologii [Agent approach in psychology] (pp. 482-497). Moscow: Institute of Psychology of the Russian Academy of Sciences. (in Russian)

Olivos, P., \& Aragonés, J. I. (2011). Propiedades psicométricas de la Escala de Identidad Ambiental (EID). PsyEcology, 2(1), 15-24.

Prévot, A.-C., Clayton, S., \& Mathevet, R. (2018). The relationship of childhood upbringing and university degree program to environmental identity: experience in nature matters. Environmental Education Research, 24, 263-279.

Raanaas, R. K., Evensen, K. H., Rich, D., Sjıstrım, G., \& Patil, G. (2011). Benefits of indoor plants on attention capacity in an office setting. Journal of Environmental Psychology, 31(1), 99-105.

Reese, G. (2016). Common human identity and the path to global climate justice. Climatic Change, 134, 521-531

Rothschild, B. (2006). Help for the helper: The psychophysiology of compassion fatigue and vicarious trauma. New York: W.W. Norton \& Co.

Ryan, R. M., \& Deci, E. L. (2003). On assimilating identities to the self: A self-determination theory perspective on internalization and integrity within cultures. In M. R. Leary \& J. P. Tangney (Eds.), Handbook of self and identity (pp. 253-272). New York: The Guilford Press. 
Schultz, P. (2000). New environmental theories: Empathizing with nature: The effects of perspective taking on concern for environmental issues. Journal of Social Issues, 56(3), 391-406.

Schultz, P. W. (2001). The structure of environmental concern: Concern for self, other people, and the biosphere. Journal of Environmental Psychology, 21(4), 327-339.

Scopelliti, M., Molinario, E., Bonaiuto, F., Bonnes, M., Cicero, L., De Dominicis, S., ... de Groot, W. (2018). What makes you a 'hero' for nature? Socio-psychological profiling of leaders committed to nature and biodiversity protection across seven EU countries. Journal of Environmental Planning and Management, 61(5-6), 970-993.

Sharafadina, K. (2011). Floropoetika kak kod bytovoj prozy XIX veka (Dnevnik i literaturnye opyty Anny Oleninoj) [Floropoetics as a code of everyday prose in the XIX century (The diary and literary works of Anna Olenina)]. Acta Universitatis Lodziensis. Folia Litteraria Rossica, 4, 75-81. (in Russian)

Stern, P. C., \& Dietz, T. (1994). The value basis of environmental concern. Journal of Social Issues, 50(3), 65-84.

Tam, K. P. (2013, a). Concepts and measures related to connection to nature: Similarities and differences. Journal of Environmental Psychology, 34, 64-78.

Tam, K. P. (2013, b). Dispositional empathy with nature.Journal of Environmental Psychology, 35, 92-104.

Watson, L., Hegtvedt, K. A., Johnson, C., Parris, C. L., \& Subramanyam, S. (2017). When legitimacy shapes environmentally responsible behaviors: Considering exposure to university sustainability initiatives. Education Sciences, 7(1), 13-29.

Wilson, E. O. (1984). Biophilia. Cambridge, MA: Harvard University Press.

Zhang, J. W., Howell, R. T., \& Iyer, R. (2014). Engagement with natural beauty moderates the positive relation between connectedness with nature and psychological well-being. Journal of Environmental Psychology, 38, 55-63.

\section{The Original Version of the EID Scale}

Appendix A

Instruction. Please indicate the extent to which each of the following statements describes you by using the appropriate number from the scale below.

\begin{tabular}{|c|c|c|c|c|c|c|}
\hline & Item & 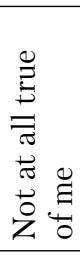 & 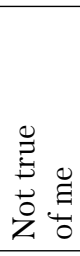 & 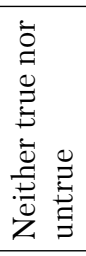 & 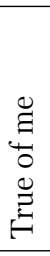 & 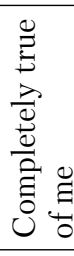 \\
\hline & & 1 & 2 & 3 & 4 & 5 \\
\hline 1 & $\begin{array}{l}\text { I spend a lot of time in natural settings (woods, moun- } \\
\text { tains, desert, lakes, ocean). }\end{array}$ & & & & & \\
\hline 2 & Engaging in environmental behaviors is important to me. & & & & & \\
\hline 3 & I think of myself as a part of nature, not separate from it. & & & & & \\
\hline 4 & $\begin{array}{l}\text { If I had enough time or money, I would certainly } \\
\text { devote some of it to working for environmental causes. }\end{array}$ & & & & & \\
\hline
\end{tabular}




\begin{tabular}{|c|c|c|c|c|c|c|}
\hline & Item & 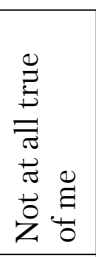 & 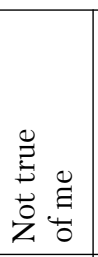 & 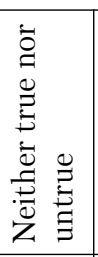 & $\begin{array}{l}\underset{\Xi}{\Xi} \\
\stackrel{0}{0} \\
\stackrel{\Xi}{E} \\
E\end{array}$ & 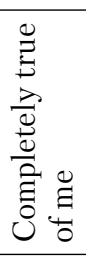 \\
\hline & & 1 & 2 & 3 & 4 & 5 \\
\hline 5 & $\begin{array}{l}\text { When I am upset or stressed, I can feel better by } \\
\text { spending some time outdoors "communing with } \\
\text { nature." }\end{array}$ & & & & & \\
\hline 6 & $\begin{array}{l}\text { Living near wildlife is important to me; I would not } \\
\text { want to live in a city all the time. }\end{array}$ & & & & & \\
\hline 7 & $\begin{array}{l}\text { I have a lot in common with environmentalists as a } \\
\text { group. }\end{array}$ & & & & & \\
\hline 8 & $\begin{array}{l}\text { I believe that some of today's social problems could be } \\
\text { cured by returning to a more rural life-style in which } \\
\text { people live in harmony with the land. }\end{array}$ & & & & & \\
\hline 9 & I feel that I have a lot in common with other species. & & & & & \\
\hline 10 & I like to garden. & & & & & \\
\hline 11 & $\begin{array}{l}\text { Being part of the ecosystem is an important part of } \\
\text { who I am. }\end{array}$ & & & & & \\
\hline 12 & $\begin{array}{l}\text { I feel that I have roots to a particular geographic loca- } \\
\text { tion that had a significant impact on my development. }\end{array}$ & & & & & \\
\hline 13 & $\begin{array}{l}\text { Behaving responsibly toward the Earth-living a sus- } \\
\text { tainable lifestyle-is part of my moral code. }\end{array}$ & & & & & \\
\hline 14 & $\begin{array}{l}\text { Learning about the natural world should be an impor- } \\
\text { tant part of every child's upbringing. }\end{array}$ & & & & & \\
\hline 15 & $\begin{array}{l}\text { In general, being part of the natural world is an impor- } \\
\text { tant part of my self-image. }\end{array}$ & & & & & \\
\hline 16 & $\begin{array}{l}\text { I would rather live in a small room or house with a nice } \\
\text { view than in a bigger room or house with a view of } \\
\text { other buildings. }\end{array}$ & & & & & \\
\hline 17 & I really enjoy camping and hiking outdoors. & & & & & \\
\hline 18 & $\begin{array}{l}\text { Sometimes I feel like parts of nature-certain trees, or } \\
\text { storms, or mountains-have a personality of their own. }\end{array}$ & & & & & \\
\hline 19 & $\begin{array}{l}\text { I would feel that an important part of my life was miss- } \\
\text { ing if I was not able to get out and enjoy nature from } \\
\text { time to time. }\end{array}$ & & & & & \\
\hline 20 & $\begin{array}{l}\text { I take pride in the fact that I could survive outdoors on } \\
\text { my own for a few days. }\end{array}$ & & & & & \\
\hline 21 & $\begin{array}{l}\text { I have never seen a work of art that is as beautiful as a } \\
\text { work of nature, like a sunset or a mountain range. }\end{array}$ & & & & & \\
\hline
\end{tabular}




\begin{tabular}{|c|c|c|c|c|c|c|}
\hline & \multirow[t]{2}{*}{ Item } & 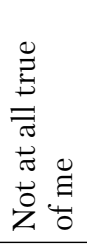 & 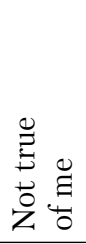 & 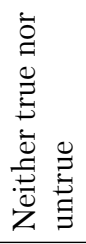 & $\begin{array}{l}\stackrel{\Xi}{\Xi} \\
\stackrel{0}{0} \\
\stackrel{\Xi}{\Xi} \\
\qquad\end{array}$ & 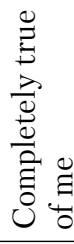 \\
\hline & & 1 & 2 & 3 & 4 & 5 \\
\hline 22 & $\begin{array}{l}\text { My own interests usually seem to coincide with the } \\
\text { position advocated by environmentalists. }\end{array}$ & & & & & \\
\hline 23 & $\begin{array}{l}\text { I feel that I receive spiritual sustenance from experi- } \\
\text { ences with nature. }\end{array}$ & & & & & \\
\hline 24 & $\begin{array}{l}\text { I keep mementos from the outdoors in my room, such } \\
\text { as shells or rocks or feathers. }\end{array}$ & & & & & \\
\hline
\end{tabular}

Susan Clayton - Whitmore-Williams Professor of Psychology, The College of Wooster, Ph.D. Research area: conservation psychology, identity, psychology of justice.

E-mail: sclayton@wooster.edu

Boris D. Irkhin - Ph.D. student, School of Psychology, Faculty of Social Sciences, National Research University Higher School of Economics.

Research area: environmental psychology, cross-cultural psychology, social psychology.

E-mail: zuroi.a@gmail.com

Sofya K. Nartova-Bochaver - professor, School of Psychology, Faculty of Social Sciences, National Research University Higher School of Economics, D.Sc., professor.

Research area: individual differences, psychology of sovereignty, environmental psychology.

E-mail: s-nartova@yandex.ru

\title{
Идентификация с природой в России: валидизация метода и связь с заботой о людях и растениях
}

\author{
С. Клейтон ${ }^{\mathrm{a}}$, Б.Д. Ирхин ${ }^{\mathrm{b}}$, С.К. Нартова-Бочавер
}

${ }^{a}$ The College of Wooster, Department of Psychology, 930 College Mall, Wooster, Ohio 44691 USA

${ }^{b}$ Национальный исследовательский университет «Высшая школа экономики», 101000, Россия, Москва, ул. Мясницкал, д. 20

\section{Резюме}

Идентификация с природой - это концепция собственной личности, определяемая отношениями с миром природы; она имеет большую ценность для прогнозирования социальных установок и поведения. В настоящей работе идентификация с природой исследуется в трех эмпирических исследованиях с использованием одноименной шкалы идентификации с природой (ИП). Исследование 1 (n = 222) было посвящено валидизации русской версии шкалы ИП. Наряду со шкалой ИП мы измеряли отношение к окружающей 
среде с помощью шкал: Новой экологической парадигмы и Глобальной осведомленности о масштабах последствий. Результаты показали, что, в соответствии с исходной версией опросника, русская версия имеет однофакторную структуру и хорошую внутреннюю согласованность $(\alpha=.88)$, что она также положительно связана с озабоченностью экологией, глобальным осознанием последствий, эгоистическими, альтруистическими и биосферическими ценностями. В исследовании $2(\mathrm{n}=94)$ изучалась связь между ИП и отношением к растительному миру с помощью опросника «Люди и растения». ИП предсказала все переменные, характеризующие отношение людей к растениям: радость, эстетику, опыт взаимодействия с растениями, близость к природе, экологию. Наконец, в исследовании $3(\mathrm{n}=200)$ изучалась связь ИП с эмпатией природе и людям. Использовались шкалы Диспозиционной эмпатии природе и Индекса межличностной реактивности. Выявлено, что ИП была положительно связана с обоими типами эмпатии и предсказывала их, при этом сильнее определяя эмпатию природе. Сделан вывод о том, что русскоязычная версия шкалы ИП является работающим надежным инструментом. Кроме того, концепция ИП, по-видимому, связана с более общей способностью контактировать с внешним миром. Как таковая, она имеет потенциал для формирования психотерапевтических программ и конструирования восстановительных окружающих сред.

Ключевые слова: идентификация с природой, эмпатия, природа, растения

\section{Русская версия Шкалы идентификации с природой}

Приложение 1

Инструкция. Пожалуйста, оцените утверждения с точки зрения того, насколько они отписывают ваше типичное отношение. Здесь нет правильных или ложных утверждений. Используя шкалу от 1 до 5, отметьте как можно более честно и откровенно, что вы чувствуете в настоящий момент.

\begin{tabular}{|c|c|c|c|c|c|c|}
\hline & \multirow[t]{2}{*}{ Утверждение } & 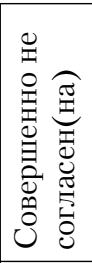 & 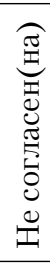 & 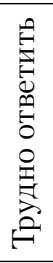 & 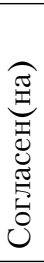 & 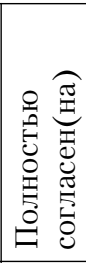 \\
\hline & & 1 & 2 & 3 & 4 & 5 \\
\hline 1 & $\begin{array}{l}\text { Я много времени провожу на природе (в лесу, в горах, } \\
\text { пустыне, на озере или в океане). }\end{array}$ & & & & & \\
\hline 2 & Я считаю заботу о природе важным делом. & & & & & \\
\hline 3 & Я считаю себя частью природы, неотделимой от нее. & & & & & \\
\hline 4 & $\begin{array}{l}\text { Если бы у меня было достаточно времени или денег, я } \\
\text { бы непременно принял(а) участие в защите природы. }\end{array}$ & & & & & \\
\hline 5 & $\begin{array}{l}\text { Когда мне грустно или я переживаю стресс, мне } \\
\text { помогает провести некоторое время наедине с } \\
\text { природой. }\end{array}$ & & & & & \\
\hline
\end{tabular}




\begin{tabular}{|c|c|c|c|c|c|c|}
\hline & Утверждение & 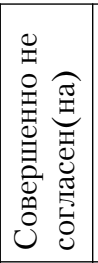 & 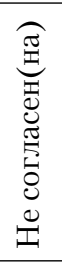 & 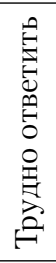 & 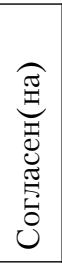 & 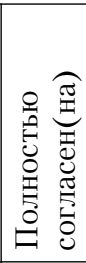 \\
\hline & & 1 & 2 & 3 & 4 & 5 \\
\hline 6 & $\begin{array}{l}\text { Мне важно жить рядом с природой; я не хотел(а) бы } \\
\text { все время жить в большом городе. }\end{array}$ & & & & & \\
\hline 7 & Я много взаимодействую с защитниками природы. & & & & & \\
\hline 8 & $\begin{array}{l}\text { Я верю, что многие социальные проблемы } \\
\text { современности могут быть излечены возвращением к } \\
\text { сельской жизни, где люди живут в гармонии с } \\
\text { природой. }\end{array}$ & & & & & \\
\hline 9 & Я чувствую свое родство с другими живыми видами. & & & & & \\
\hline 10 & Я люблю работать в саду. & & & & & \\
\hline 11 & Я часть экосистемы, и это для меня важно. & & & & & \\
\hline 12 & $\begin{array}{l}\text { Я чувствую привязанность к некоторому } \\
\text { географическому месту, которое оказало серьезное } \\
\text { влияние на мое развитие. }\end{array}$ & & & & & \\
\hline 13 & $\begin{array}{l}\text { Вести себя ответственно по отношению к Земле - } \\
\text { практиковать устойчивый стиль жизни - это часть } \\
\text { моего морального кодекса. }\end{array}$ & & & & & \\
\hline 14 & $\begin{array}{l}\text { Знакомство с природой должно быть важной частью } \\
\text { воспитания каждого ребенка. }\end{array}$ & & & & & \\
\hline 15 & $\begin{array}{l}\text { В общем и целом, быть себя частью природы важно } \\
\text { для моего представления о себе. }\end{array}$ & & & & & \\
\hline 16 & $\begin{array}{l}\text { Я бы предпочел(ла) маленькую квартиру с хорошим } \\
\text { видом из окна просторному жилью с видом на } \\
\text { застроенный район. }\end{array}$ & & & & & \\
\hline 17 & $\begin{array}{l}\text { Мне нравится ходить в походы и ночевать на } \\
\text { природе. }\end{array}$ & & & & & \\
\hline 18 & $\begin{array}{l}\text { Иногда я чувствую, что явления природы - деревья, } \\
\text { ветер или горы - тоже имеют личность. }\end{array}$ & & & & & \\
\hline 19 & $\begin{array}{l}\text { Если бы у меня не было возможности быть на } \\
\text { природе, из моей жизни пропало бы нечто очень } \\
\text { важное. }\end{array}$ & & & & & \\
\hline 20 & $\begin{array}{l}\text { Я горжусь тем, что могу прожить несколько дней в } \\
\text { природных условиях. }\end{array}$ & & & & & \\
\hline
\end{tabular}




\begin{tabular}{|c|c|c|c|c|c|c|}
\hline & \multirow[t]{2}{*}{ Утверждение } & 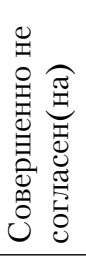 & 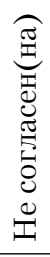 & 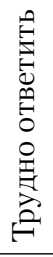 & 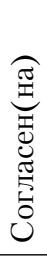 & 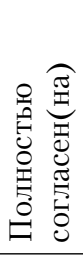 \\
\hline & & 1 & 2 & 3 & 4 & 5 \\
\hline 21 & $\begin{array}{l}\text { Я не знаю произведений искусства столь же } \\
\text { прекрасных, как природа - закат солнца или горная } \\
\text { гряда. }\end{array}$ & & & & & \\
\hline 22 & $\begin{array}{l}\text { Мои интересы обычно совпадают с позицией } \\
\text { защитников природы. }\end{array}$ & & & & & \\
\hline 23 & Общение с природой духовно «подпитывает» меня. & & & & & \\
\hline 24 & $\begin{array}{l}\text { Я храню дома сувениры, принесенные с прогулок на } \\
\text { природе, - ракушки, камни, птичьи перья. }\end{array}$ & & & & & \\
\hline
\end{tabular}

Клейтон Сьюзен - Витмор-Вилльямс профессор психологии, Вустер-колледж, доктор психологии.

Сфера научных интересов: психология охраны среды, идентичность, психология справедливости.

Контакты: sclayton@wooster.edu

Ирхин Борис Денисович - аспирант, факультет социальных наук, департамент психологии, Национальный исследовательский университет «Высшая школа экономики».

Сфера научных интересов: психология среды, кросс-культурная психология, социальная психология.

Контакты: zuroi.a@gmail.com

Нартова-Бочавер Софья Кимовна - профессор, департамент психологии, факультет социальных наук, Национальный исследовательский университет «Высшая школа экономики», доктор психологических наук, профессор.

Сфера научных интересов: психология индивидуальных различий, психология суверенности, психология среды.

Контакты: s-nartova@yandex.ru 